\title{
Renewal of the editorial office and board
}

\author{
Kazunori Sato
}

Published online: 8 December 2012

(C) The Society of Population Ecology and Springer Japan 2012

I would like to announce that I replace Dr. Takashi Saitoh in his post as an editor in chief and a part of associate editors and editorial board members are replaced. In addition, we make a special feature editor as a new position. We start editing of Population Ecology by new editorial members from this new year 2013.

The impact factor of Population Ecology for 2011 went beyond 2.0 and rose up to 2.287 . This happy news proves that Population Ecology has been still growing as an international journal and publishing articles with high quality. From the theoretical ecological point of view it may not be good to put too much confidence in only one index, but I believe that the impact factor is one of the most reliable indices to judge the value of scientific journals objectively. Then we will make every effort to enhance the value of impact factor and so attempt new trials to increase the number of submissions in all article types to Population Ecology.

In the last 2 years 136 papers were submitted from over 36 countries in 2011, and the number of papers submitted had already exceeded 150 by November 2012. Unfortunately, however, we feel the shortage of the submissions of special features (for example, no special features in the previous volume), so we expect for special feature editors as new editorial members to encourage mainly these submissions. We continually welcome the submissions of all article types; Original articles, Reviews, Notes and Comments, Forum, Special Features.

\section{K. Sato $(\square)$}

Department of Systems Engineering, Faculty of Engineering,

Shizuoka University, 5-1 Johoku 3-chome, Naka-ku,

Hamamatsu 432-8561, Japan

e-mail: sato@sys.eng.shizuoka.ac.jp
Although core articles of Population Ecology are original research and review papers, we encourage authors to contribute 'Notes and Comments' or 'Forum' papers. A 'Notes and Comments' article would be (a) brief notes on both empirical and theoretical investigations (see Ramesh et al. 2013 in this issue for an example), or (b) critical comments on previously published papers to develop further discussion (see DeVink et al. 2011; McKelvery et al. 2011; Hargrove et al. 2011; Cayuela et al. 2011). A 'Forum' article would be (a) discussions on new concepts, analyses and data that are significant for population ecology (see Ma 2011), or (b) a short review or a review in a small arena.

"Population Ecology" is now an interdisciplinary field. For example, the abundance of population obtained from field or experimental studies is usually examined statistically to validate the underlying assumption or reject the null hypothesis. On the other hand, the mathematical models describing population dynamics can support the underlying mechanism of time series data from real observations in natural ecosystems. Statistical approach and mathematical modeling for ecological data should become great help to each other, but in the present there are not so many studies using both of them to deal with empirical data. We are promoting the unified study by mathematics, statistics and ecological data.

\section{Photos on the cover page}

One photo was selected from an article published in 2011 and three others were selected from the previous volume published in 2012.

Unlike workers, which are bound to their colony, male bumblebees lead solitary, self-provisioning life once they 
left the colony (upper left). Population genetics reveal temporally consistent significant differences between the local male and worker gene pool in two common European bumblebee species explained by spatially extended male dispersal rates (Wolf et al. 2012). The increased number of colonies potentially contributing to the local gene pool increases the effective population size, a proxy for population fitness.

The orb web spider Argiope bruennichi (upper right) commonly found in Satoyama landscapes in Japan. Although the local habitats of this species are grasslands, creeks, and paddy fields, Miyashita et al. (2012) revealed that its abundance was highest in grasslands with moderate levels of forest surroundings.

A common cuckoo (Cuculus canorus) chick is in the nest of great reed warblers (Acrocephalus arundinaceus) in Hungary (lower left). These hosts recognize and reject about one-third of the cuckoo eggs as antiparasite defence. Increased host tolerance toward multiple parasitism contributes to both parasite abundance and parasitism rate being kept at a high level (Takasu and Moskát 2011).

A polar bear family in Foxe Basin, a seasonally ice-free habitat, where bears spend the autumn on land (lower right). Females and cubs in nearby populations in Baffin Bay and Davis Strait, where ice is similarly seasonal, have recently exhibited annual variation in body condition coinciding with available ice habitat and declines in body condition. These relationships were not apparent in the 1970s to 1990s, prior to declines in sea ice habitat (Rode et al. 2012).

\section{References}

Cayuela L, Gálvez-Bravo L, Carrascal LM, de Albuquerque FS (2011) Comments on Bartolino et al. (2011): limits of cumulative relative frequency distribution curves for hotspot identification. Popul Ecol 53:597-601

DeVink J-M, Berezanski D, Imrie D (2011) Comments on Brodie and Post: harvest effort: the missing covariate in analyses of furbearer harvest data. Popul Ecol 53:261-262

Hargrove JW, Torr SJ, Vale AG (2011) Comment on Barclay and Vreysen: published dynamic population model for tsetse cannot fit field data. Popul Ecol 53:413-415

Ma Z (2011) Did we miss some evidence of chaos in laboratory insect populations? Popul Ecol 53:405-412

McKelvery KS, Lofroth EC, Copeland JP, Copeland JP, AUbry KB, Magoun AJ (2011) Comments on Brodie and Post: Climatedriven declines in wolverine populations: causal connection or spurious correlation? Popul Ecol 53:263-266

Miyashita T, Chishiki Y, Takagi SR (2012) Landscape heterogeneity at multiple spatial scales enhances spider species richness in an agricultural landscape. Popul Ecol 54:573-581

Ramesh D, Home C, Jhala YV, Quereshi Q (2013) Calibration of a burrow count index for the Indian desert jird, Meriones hurrianae. Popul Ecol 55:241-245

Rode KD, Peacock E, Taylor M, Stirling I, Born EW, Laidre KL, Wiig Ø (2012) A tale of two polar bear populations: ice habitat, harvest, and body condition. Popul Ecol 54:3-18

Takasu F, Moskát C (2011) Modeling the consequence of increased host tolerance toward avian brood parasitism. Popul Ecol 53:187-193

Wolf S, Toev T, Moritz RLV, Moritz RFA (2012) Spatial and temporal dynamics of the male effective population size in bumblebees (Hymenoptera: Apidae). Popul Ecol 54:115-124 